\title{
Sponge-rhodolith interactions in a subtropical estuarine system
}

\author{
Enrique Ávila • Rafael Riosmena-Rodríguez • \\ Gustavo Hinojosa-Arango
}

Received: 27 March 2012/Revised: 3 August 2012/ Accepted: 9 August 2012/Published online: 25 August 2012

(C) Springer-Verlag and AWI 2012

\begin{abstract}
The interactions between sponges and red macroalgae have been widely documented in tropical and subtropical environments worldwide, and many of them have been documented as mutualistic associations. Sponges, however, have also been frequently described as part of the associated fauna of rhodolith habitats (aggregations of freeliving non-geniculated coralline macroalgae). Nonetheless, the types of interaction they establish as well as the role of sponges in these habitats remain unknown. In this study, the associations between sponges and rhodoliths were investigated in an estuarine ecosystem of the Mexican Pacific based on qualitative and quantitative data. A total of 13 sponge species were identified in five newly discovered rhodolith beds dominated by the non-geniculate coralline macroalga Lithophyllum margaritae. The sponge assemblages were strongly restricted to rhodolith habitats. The best predictor of
\end{abstract}

Communicated by H.-D. Franke.

Present Address:

E. Ávila $(\bowtie)$

Estación El Carmen, Instituto de Ciencias del Mar y Limnología,

Universidad Nacional Autónoma de México,

Carretera Carmen-Puerto Real km. 9.5,

24157 Ciudad del Carmen, Campeche, Mexico

e-mail: kike@ola.icmyl.unam.mx

E. Ávila $\cdot$ R. Riosmena-Rodríguez

Departamento de Biología Marina,

Programa de Investigación en Botánica Marina,

Universidad Autónoma de Baja California Sur,

Apartado postal, 19-B, $23080 \mathrm{La} \mathrm{Paz}$,

Baja California Sur, México

G. Hinojosa-Arango

The School for Field Studies,

Puerto de Acapulco s/n, Puerto San Carlos,

23740 Comondú, Baja California Sur, Mexico

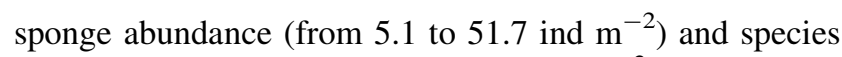
richness (from 2.6 to 6.1 sponge species $\mathrm{m}^{-2}$ ) was the rhodolith density rather than other population descriptors assessed (e.g., average size, branch density and sphericity). The identified sponges included a variety of forms: massive (46\%), encrusting (23\%), excavating (15\%), cushionshape $(8 \%)$ and digitate $(8 \%)$. Moreover, more than $50 \%$ of sponge species recorded (mainly massive and encrusting forms) were frequently found overgrowing and binding rhodoliths. Halichondria cf. semitubulosa and Mycale cecilia were the most common binding agents; these species bind an average of 3.1 and 6.6 rhodoliths per sponge individual, respectively. These findings reveal the importance of rhodoliths as habitat forming species, since these seaweed beds notably increased the substrate complexity in soft bottom environments. In addition, the relatively high abundance of sponges and their capability to bind rhodoliths suggest that these associated organisms could have an important contribution to rhodolith bed stability.

Keywords Rhodolith beds - Sponge assemblages . Abundance $\cdot$ Species richness $\cdot$ Rhodoliths stabilization · East Pacific

\section{Introduction}

Interactions between sponges and macroalgae have been recorded worldwide and are often considered to be mutualistic associations (see review by Wulff 2006). In such interactions, sponges may gain (1) structural support (Vacelet 1981; Rützler 1990; Trautman et al. 2000; Calcinai et al. 2006; Carballo et al. 2006); (2) organic compounds derived from algal photosynthesis (Grant and Hinde 1999; Davy et al. 2002); (3) protection against predation (Wulff 
1997) and (4) enhance its spatial distribution (from waveprotected to wave-exposed sites) (Carballo et al. 2006). In return, the alga may (1) reach bigger size and acquire structural protection against abrasive hydrodynamics (Trautman et al. 2000; Carballo et al. 2006; Calcinai et al. 2006), (2) expand their photosynthetic surfaces in order to reduce self-shading and increase their distribution range with depth (Enríquez et al. 2009), (3) enhance their dispersal capacity through fragmentation (Carballo et al. 2006) and (4) receive nitrogenated compounds provided by the sponge catabolism (Davy et al. 2002).

Typically, in most of these associations, the associated macroalga belongs to the Division Rhodophyta, within which the interactions with geniculate coralline algae are frequent (Ávila et al. 2010). These invertebrates have also been commonly reported as conspicuous inhabitants of rhodolith beds (free-living non-geniculate coralline algae, also known as maerl) (e.g., Solórzano et al. 1991; Steller et al. 2003; Aguilar et al. 2009; Sciberras et al. 2009). However, the types of interaction they can establish as well as the possible role of sponges in these habitats remain unknown. In some instances, it has been suggested that sponges and other fouling organisms (e.g., tunicates and anemones) could reduce the movement of rhodoliths and therefore affect their sphericity (Steller and Foster 1995; Marrack 1999; Foster 2001). It has also been argued that boring sponges may have an important role in the bioerosion process of these calcareous substrata (Leal et al. 2012).

Recent expeditions along the Mexican Pacific coasts have revealed the presence of new rhodolith beds in shallow estuarine systems of the Mexican Pacific (Ávila and Riosmena-Rodríguez 2011). These habitats are characterized by a noticeable diversity and abundance of associated organisms, including sponges. According to preliminary observations, most of the sponge species show encrusting and massive growth forms and were observed overgrowing rhodoliths. The role of sponges as binding organisms in other contexts is better known, as they have been widely documented in coral reefs and in temperate rocky habitats (see review by Bell 2008). In coral reefs, for example, sponges and other organisms participate in regeneration processes through rubble stabilization (Wulff 1984; Scoffin and Hendry 1984; Rasser and Riegl 2002). In rhodolith beds, however, the role of sponges as substrate stabilizers as well as its potential effects (positive or negative) on these algae and the associated biota has not been previously investigated.

It is also known that rhodoliths provide a hard substrate that notably increases the substrate complexity and therefore the availability of microhabitats (Foster et al. 1997; Steller et al. 2003). This structural complexity together with the coverage of living rhodoliths appears to be a good predictor of both abundance and species richness of associated organisms (Steller et al. 2003). Most of the studies have generally been conducted on the entire rhodolith community, including infauna and organisms that inhabit between rhodolith branches (Hinojosa-Arango and Riosmena-Rodríguez 2004; Harvey and Bird 2008). However, it is unknown whether the structural characteristics (e.g., size, branch density and sphericity) and density of rhodoliths can have influence in the diversity and abundance of relatively larger invertebrates such as sponges.

The aims of the present study were therefore: (1) to describe the diversity and abundance of sponges associated with the newly discovered rhodolith beds in the Mexican Pacific coasts, (2) to determine whether the species richness and the abundance of sponges vary as a function of rhodolith structure (size, sphericity and branch density) and abundance and (3) to assess the potential role of sponges as rhodolith bed stabilizers.

\section{Materials and methods}

\section{Study area}

The study area is located in Bahia Magdalena, a coastal lagoon system situated between $24^{\circ} 15^{\prime} \mathrm{N}$ and $25^{\circ} 20^{\prime} \mathrm{N}$ and $111^{\circ} 30^{\prime} \mathrm{W}$ and $112^{\circ} 15^{\prime} \mathrm{W}$ on the Pacific coast of Mexico (Fig. 1). The lagoon is an irregularly shaped anti-estuarine system (without freshwater influx and high evaporation) composed of intertidal and shallow areas and relatively narrow mangrove channels with an average depth of $3.5 \mathrm{~m}$ (Schweers et al. 2006). The sea surface temperatures range from $20^{\circ} \mathrm{C}$ during January and February to $27^{\circ} \mathrm{C}$ in September (Lluch-Belda et al. 2000). In the shallower zones, salinities reach highs (39.2) in July-August and lows (34.1) in March. The tidal regime (24.8 h) is mixed semidiurnal, with periods of higher high water followed by those of lower low water, a condition that produces greater current velocities during ebb tides (Lankford 1977; ObesoNieblas et al. 1999).

Within this estuarine system, five rhodolith beds were found between August 2008 and February $2009\left(\operatorname{Bed} 1: 24^{\circ} 48^{\prime} 45^{\prime \prime} \mathrm{N}-\right.$ $112^{\circ} 05^{\prime} 59^{\prime \prime} \mathrm{W}$; Bed 2: $24^{\circ} 54^{\prime} 12^{\prime \prime} \mathrm{N}-112^{\circ} 05^{\prime} 24^{\prime \prime} \mathrm{W}$; Bed 3: $24^{\circ} 53^{\prime} 47^{\prime \prime} \mathrm{N}-112^{\circ} 06^{\prime} 29^{\prime \prime} \mathrm{W}$; Bed 4: $24^{\circ} 48^{\prime} 42^{\prime \prime} \mathrm{N}-112^{\circ} 06^{\prime} 32^{\prime \prime} \mathrm{W}$; Bed 5: $\left.24^{\circ} 51^{\prime} 47^{\prime \prime} \mathrm{N}-112^{\circ} 07^{\prime} 14^{\prime \prime} \mathrm{W}\right)$. These seaweed habitats were found at depths between 1 and $3 \mathrm{~m}$ in relatively narrow areas bordered by mangrove. The bottom in adjacent areas of beds 1, 3, 4 and 5 was sandy with small sea grass patches, whereas in the bed 2 , the bottom was constituted by consolidated calcareous rocks with small sections of sand.

Abundance of sponges and rhodoliths

At each rhodolith bed, three interrupted (with intervals of $5 \mathrm{~m}$ ) line transects of $20 \mathrm{~m}$ were placed perpendicular to 
Fig. 1 Study area at Bahia Magdalena, Mexico. Numbers indicate the location of the five rhodolith beds

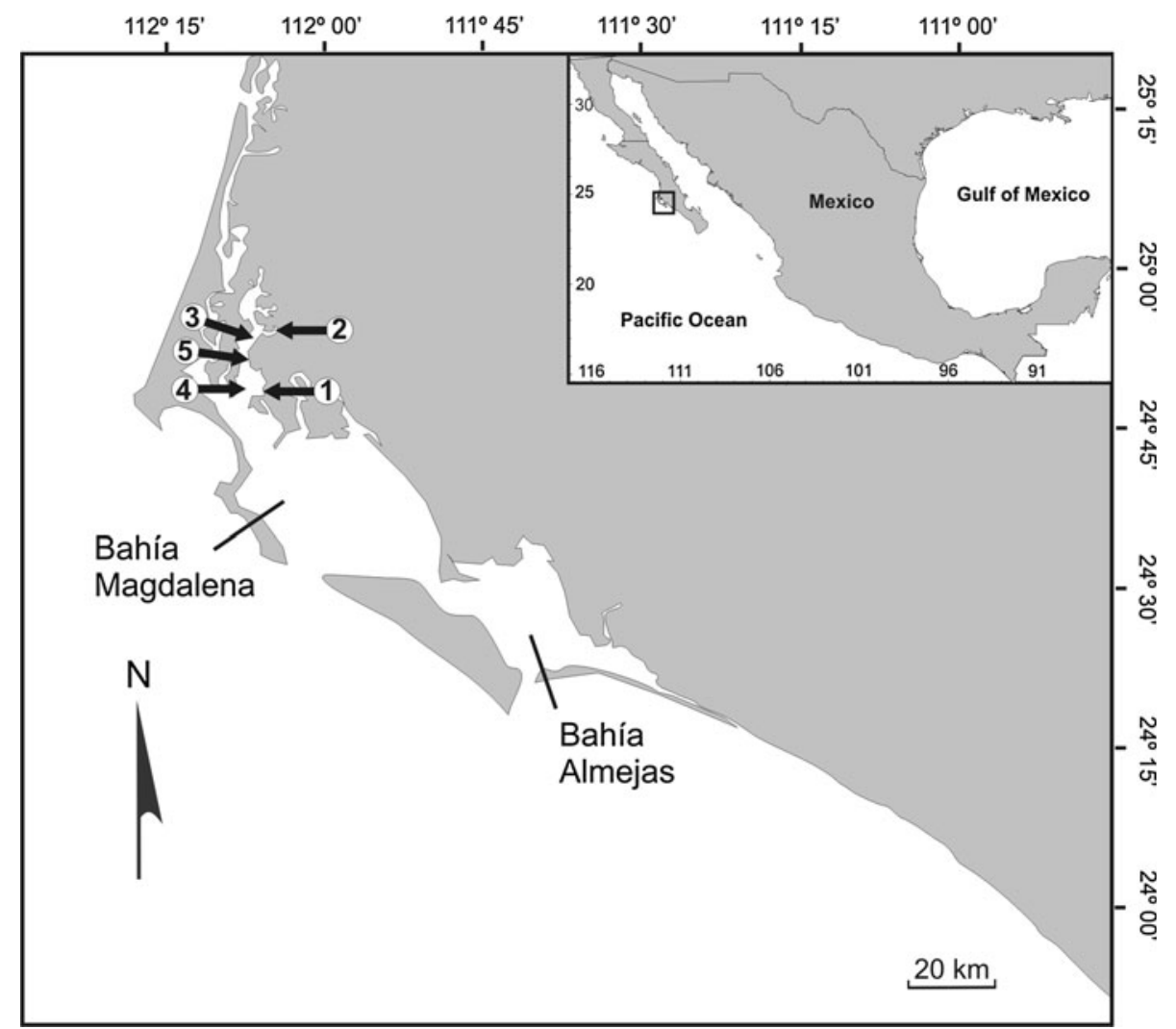

the shore (between 1 and $2 \mathrm{~m}$ depth). Then, one meter square quadrant was placed every five meters along each transect, and the total number of sponges and live rhodoliths present on the surface area of bed were visually quantified. In this study, an individual of sponge was defined as being any sponge growing independently (without contact) (Carballo et al. 2008). In some instances, rhodoliths were collected to determine the number of sponges growing on them. Also the number of sponge species within each quadrat was recorded. The total sampled area in each site was $15 \mathrm{~m}^{2}$. The abundance of sponges and live rhodoliths was expressed as individuals/ $\mathrm{m}^{2}$ and the sponge species richness as the number of sponge species $/ \mathrm{m}^{2}$ (Fig. 2).

In addition, to compare the sponge abundance in and out the rhodolith bed, another three transects (20 m length) were placed (at the same depth and perpendicular to the shore) at a distance of $10 \mathrm{~m}$ from the bed. This procedure was done on the adjacent zone of beds 1 and 2 . In these sites, the substrate was sandy. The particle size of the surface sediment (first $10 \mathrm{~cm}$ ) in both sites was generally fine sand, with approximately $50 \%$ of the sediment composed of material finer than $<0.5 \mathrm{~mm}$.
Rhodolith size and shape

In order to determine whether the abundance and richness of sponges vary among rhodolith beds according to the rhodolith size and shape, the average size $(\mathrm{cm})$, sphericity and branch density (branches $/ \mathrm{cm}^{2}$ ) of rhodoliths was determined. Rhodolith samples were collected in $0.25 \times 0.25 \mathrm{~m}$ quadrats placed in the left superior corner of each $1 \mathrm{~m}^{2}$ quadrat used for abundance determinations (15 samples per site). Individuals were placed into plastic bags separately and transported to the laboratory.

For each individual, its sphericity was calculated by measuring the longest, shortest and intermediate axes (see detailed method in Bosence and Pedley 1982; Graham and Midgley 2000). The average size was measured considering the longest dimension (Steller and Foster 1995). Branch density of each individual was estimated as the mean number of apical tips counted in three haphazardly placed $1 \mathrm{~cm}^{2}$ quadrats (Steller and Foster 1995). The percent live surface area of rhodoliths was estimated based on pigmentation analysis of the coralline algae thallus surface (Bahia et al. 2010). 

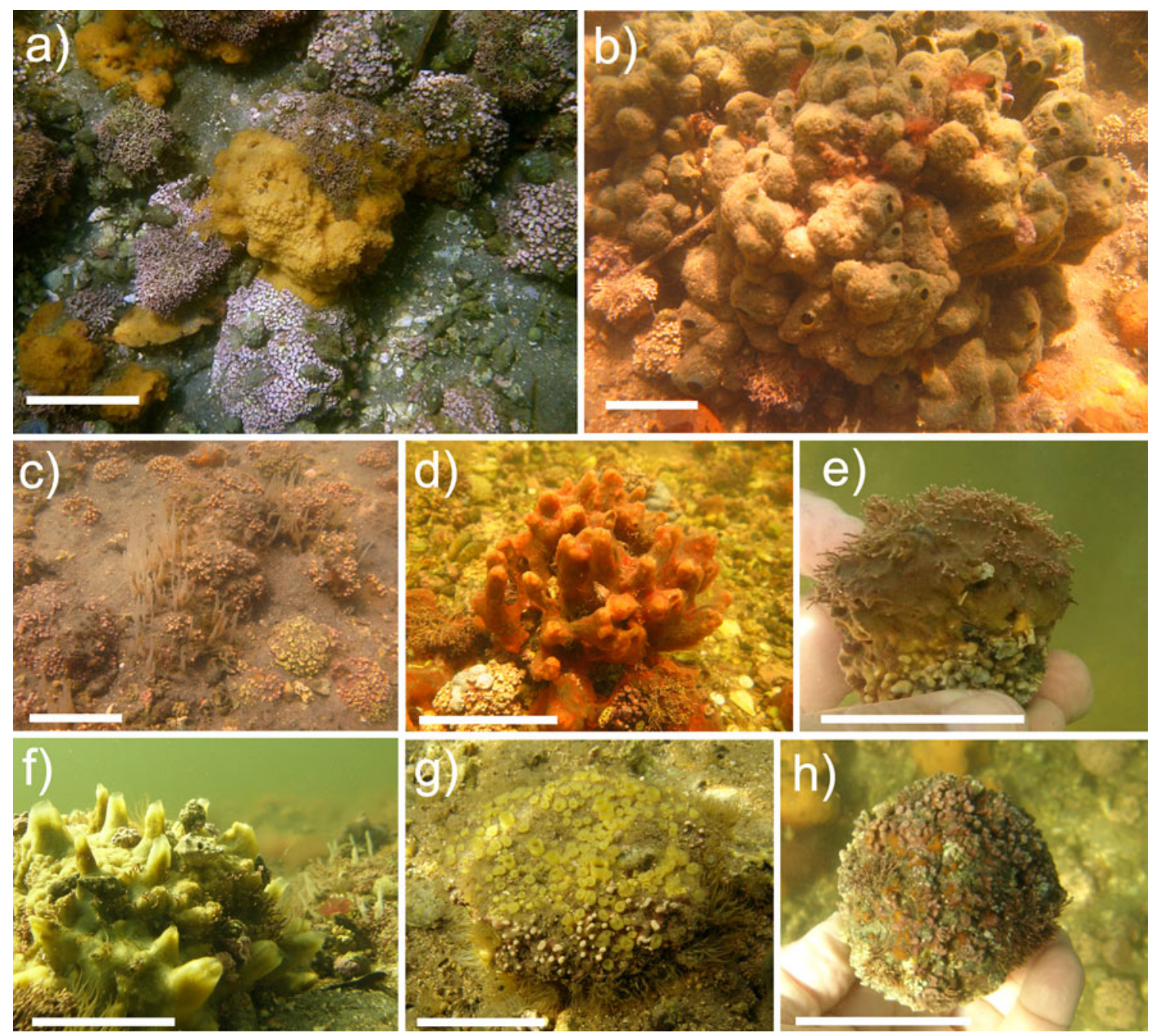

Fig. 2 The most common sponge species associated with rhodolith beds from Bahia Magdalena: a Scopalina sp., b Suberites aurantiaca, c Halichondria semitubulosa, d Mycale cecilia, e Mycale cf.

Rhodolith collections were carried out in November 2008 in beds 1 and 2, and between January and February 2009 for beds 3, 4 and 5. The coverage area of beds was estimated by taking a series of geographical coordinates around the margins of each bed. The Garmin MapSource program was used to calculate the area $\left(\mathrm{km}^{2}\right)$.

\section{Rhodolith stabilization by sponges}

In order to examine the potential role of sponges as rhodolith stabilizers, the abundance of sponges that bind two or more rhodoliths together was determined. The abundance (individuals $/ \mathrm{m}^{2}$ ) of these sponge species was quantified in three $10 \times 1.0 \mathrm{~m}$ transects (replicates) randomly placed within beds 1 and 2. Also, the total number of rhodoliths that every sponge attached to was recorded in each transect. A total area of $30 \mathrm{~m}^{2}$ was sampled in each site. magnirhapidifera, f Halichondria panicea, g Cliona californiana and $\mathbf{h}$ Cliona euryphylla. The species from $\mathbf{a}-\mathbf{f}$ were the most common sponges binding rhodoliths in Bahia Magdalena. Scale $=5 \mathrm{~cm}$

Data analysis

One-way analyses of variance (ANOVA) followed by the Student-Newman-Keuls tests were used to assess significant differences in the mean density and structure of rhodoliths (size and branch density), and differences in the mean density and richness of sponges between sites (site was a random factor: 5 levels). For these cases, the average value of each transect was used as replicate (3 replicates/ site). To determine whether the abundance of sponges that binds rhodoliths together varied between rhodolith beds ( 2 sites), one-way ANOVA was performed. Spearman rank correlations were used to assess relationships between the abundance and richness of sponges and abundance, size and branch density of rhodoliths. The average value of each quadrat was used as replicate in these analyses (15/site). The assumptions of normality and homocedasticity in each variable were previously tested by 
Table 1 Summary of the rhodolith shape analysis (size, branch density and sphericity)

\begin{tabular}{|c|c|c|c|c|c|}
\hline & Bed 1 & Bed 2 & Bed 3 & Bed 4 & Bed 5 \\
\hline Size $(\mathrm{cm})$ & $5.6 \pm 0.1$ & $5.9 \pm 0.2$ & $5.9 \pm 0.2$ & $5.5 \pm 0.1$ & $6.2 \pm 0.3$ \\
\hline Branches $\mathrm{cm}^{-2}$ & $11.2 \pm 0.2$ & $9.4 \pm 0.3$ & $6.9 \pm 0.2$ & $5.5 \pm 0.2$ & $7.2 \pm 0.3$ \\
\hline Spherical forms (\%) & 99.0 & 80.8 & 87.6 & 81.4 & 75.0 \\
\hline Discoidal forms (\%) & 0.0 & 5.0 & 2.1 & 9.3 & 9.0 \\
\hline Ellipsoidal forms (\%) & 1.0 & 14.2 & 10.3 & 9.3 & 17.0 \\
\hline Individuals measured & 100 & 87 & 100 & 100 & 35 \\
\hline
\end{tabular}

The table shows the average $( \pm \mathrm{SE})$ dimensions of rhodolith samples collected from five beds in Bahia Magdalena in September and November 2008

Kolmogorov-Smirnov's and Bartlett's tests, respectively (Sokal and Rohlf 1995).

\section{Results}

Rhodolith bed structure

Rhodolith beds ranged from 7,000 to 20,000 $\mathrm{m}^{2}$ approximately, and the dominant rhodolith forming species was Lithophyllum margaritae Hariot. This seaweed showed fruticose and foliose growth forms. The structural characteristics (shape, size and branch density) of rhodoliths from each bed are summarized in Table 1.

The percent live surface area of rhodoliths was of $100 \%$, as all individuals collected showed a characteristic pinkish pigmentation. Only a few individuals showed bleached portions. Spherical forms were the most common morphology in all rhodolith beds, representing more than $75 \%$ of the total samples for all 5 beds (Table 1). The average size of rhodoliths ranged from $5.5 \pm 0.1$ to $6.2 \pm 0.3 \mathrm{~cm}$ with predominant size classes of $40-60 \mathrm{~mm}$. The average size and branch density showed significant differences (ANOVA, size: $p<0.05$; branch density: $p<0.05)$ between sites. Rhodoliths from bed 1 showed larger sizes $(p<0.05)$ and had higher branch densities than those of the other four sites (Table 1$)$. The average $( \pm \mathrm{SE})$ density of rhodoliths ranged from $31.8 \pm 5.2$ ind $\mathrm{m}^{-2}$ (bed 5) to $215.9 \pm 3.02$ ind $\mathrm{m}^{-2}$ (bed 1) (Table 1), and there were not significant differences among the five sites.

Sponge richness and abundance

Thirteen sponge species belonging to 6 Orders and 8 Families were recorded in association with rhodolith beds from Bahia Magdalena (Table 2). These assemblages were characterized by a variety of growth forms: massive (46\%), encrusting (23\%), excavating (15\%), cushionshape $(8 \%)$ and digitate $(8 \%)$. The sponge species richness varied significantly (ANOVA, $p<0.01$ ) between sites. Richness was significantly higher (SNK test, $p<0.01)$ in bed $1\left(6.1 \pm 0.8\right.$ species $\left.\mathrm{m}^{-2}\right)$ than in bed 2 $\left(2.7 \pm 0.6\right.$ species $\left.\mathrm{m}^{-2}\right)$, bed $3\left(2.6 \pm 0.2\right.$ species $\left.\mathrm{m}^{-2}\right)$ and bed 5 (3.6 \pm 0.4 species $\left.\mathrm{m}^{-2}\right)$. However, richness was not significantly different (SNK test, $p>0.05$ ) than those recorded in bed $4\left(5.1 \pm 0.5\right.$ species $\left.\mathrm{m}^{-2}\right)$.

The overall sponge abundance ranged from 5.1 to 51.7 ind $\mathrm{m}^{-2}$ and showed significant (ANOVA, $p<0.01$ ) variations between sites. Abundance was significantly (SNK test, $p<0.01$ ) higher in bed 1 (total average density $=51.7 \pm 6.9$ ind $\mathrm{m}^{-2}$ ) than in the other four beds. The most abundant species in all sites were: Scopalina sp., Halichondria cf. semitubulosa, Haliclona sp., Mycale cecilia and Halichondria panicea (Table 2).

Spearman rank correlation analyses indicated that the sponge species richness and sponge density were positively correlated (species richness: $r=0.59, p<0.01$; abundance: $r=0.86, p<0.01)$ with the rhodolith density (Fig. 3a, b), that is, the number of sponges species and their abundance increased as a function of rhodolith density.

Moreover, when comparing the abundance of sponges outside versus inside these algal beds, sponges were not present in adjacent sandy areas.

\section{Sponges as rhodolith stabilizers}

Seven sponge species were identified as binding agents in the rhodolith beds of Bahia Magdalena: $H$. cf. semitubulosa, M. cecilia, H. panicea, Suberites aurantiaca, Scopalina sp., Cliona euryphylla and Haliclona sp. (Fig. 4). Six of them were present in bed 1 and three in bed 2. The mean abundance of these species was significantly (ANOVA, $p<0.01)$ higher in bed $1\left(4.3 \pm 0.14 \mathrm{ind}^{-2}\right)$ than in bed $2\left(1.5 \pm 0.07\right.$ ind $\left.\mathrm{m}^{-2}\right)$.

The most abundant species in bed 1 was $H$. cf. semitubulosa $\left(3.2 \pm 0.2\right.$ ind $\left.\mathrm{m}^{-2}\right)$. This species was found binding an average of $3.1 \pm 0.2$ rhodoliths per sponge individual. In bed 2, the most abundant species was $M$. cecilia $\left(0.6 \pm 0.4\right.$ ind $\left.\mathrm{m}^{-2}\right)$, which bound an average of $6.6 \pm 2.0$ rhodoliths/individual (Fig. 4). Twenty-one rhodoliths was the maximum number of rhodoliths attached by a single sponge (M. cecilia in bed 1). Although the 
Table 2 Composition and average density (individuals $\mathrm{m}^{-2} \pm \mathrm{SE}$ ) of the sponges surveyed from five rhodolith beds in Bahia Magdalena

\begin{tabular}{|c|c|c|c|c|c|c|}
\hline Sponge species & Growth form & Bed 1 & Bed 2 & Bed 3 & Bed 4 & Bed 5 \\
\hline Scopalina sp. & $\mathrm{E}, \mathrm{M}$ & $21.5 \pm 1.8$ & $1.3 \pm 0.8$ & $0.3 \pm 0.2$ & $1.9 \pm 0.7$ & $2.0 \pm 0.7$ \\
\hline Halichondria panicea & M & $2.1 \pm 0.6$ & $1.9 \pm 1.9$ & $0.1 \pm 0.0$ & $0.8 \pm 0.1$ & $1.3 \pm 0.8$ \\
\hline Halichondria cf. semitubulosa & $\mathrm{D}$ & $20.0 \pm 3.6$ & $2.8 \pm 1.0$ & $1.9 \pm 0.3$ & $6.9 \pm 1.3$ & $2.2 \pm 0.4$ \\
\hline Mycale cf. magnirhapidifera & $\mathrm{E}$ & $2.1 \pm 1.0$ & $0.3 \pm 0.0$ & $0.1 \pm 0.0$ & $0.7 \pm 0.2$ & $0.3 \pm 0.4$ \\
\hline Mycale cecilia & $\mathrm{E}, \mathrm{M}$ & $3.3 \pm 1.0$ & - & - & $2.4 \pm 1.3$ & $2.2 \pm 0.5$ \\
\hline Suberites aurantiaca & M & $0.1 \pm 0.2$ & $0.3 \pm 0.2$ & - & $0.3 \pm 0.1$ & - \\
\hline Dysidea cachui & M & $0.9 \pm 0.3$ & - & $0.1 \pm 0.0$ & $0.1 \pm 0.1$ & - \\
\hline Cliona euryphylla & Ex & $0.1 \pm 0.1$ & $0.1 \pm 0.1$ & $0.4 \pm 0.0$ & $0.1 \pm 0.1$ & $0.8 \pm 0.5$ \\
\hline Cliona californiana & Ex & $0.1 \pm 0.2$ & - & $0.1 \pm 0.0$ & $0.2 \pm 0.1$ & $1.7 \pm 0.4$ \\
\hline Haliclona sp. & $\mathrm{Cu}$ & $0.8 \pm 0.4$ & - & $2.3 \pm 0.5$ & $0.9 \pm 0.7$ & $1.0 \pm 0.0$ \\
\hline Haplosclerida sp. 1 & M & $0.7 \pm 0.6$ & - & - & $0.2 \pm 0.1$ & $0.5 \pm 0.6$ \\
\hline Haplosclerida sp. 2 & M & - & $0.2 \pm 0.1$ & - & - & - \\
\hline Clathrinida sp. & M & - & $0.1 \pm 0.1$ & $0.1 \pm 0.0$ & $1.1 \pm 0.2$ & $0.3 \pm 0.4$ \\
\hline
\end{tabular}

Growth form $E$ encrusting, $M$ massive, $D$ digitate, $E x$ excavating, $C u$ cushion-shape

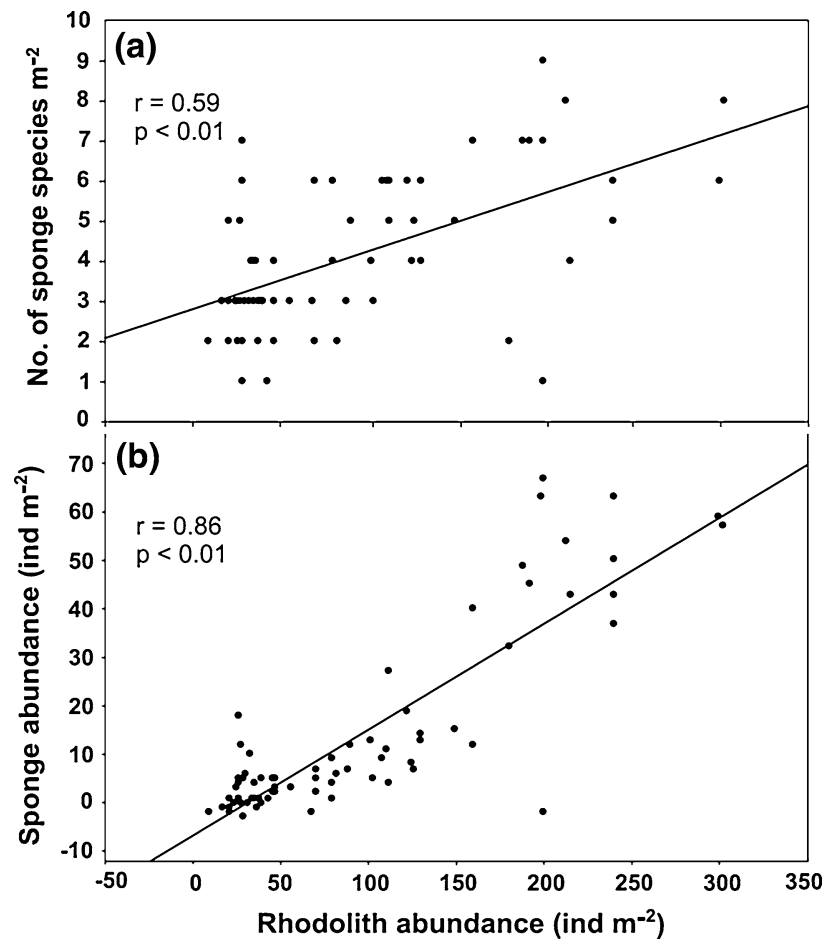

Fig. 3 a Relationships between rhodolith density and the number of sponge species $\mathrm{m}^{2}$ and $\mathbf{b}$ between rhodolith density and sponge abundance

abundance of $M$. cecilia was relatively lower than those of $H$. semitubulosa, individuals of $M$. cecilia generally showed a larger coverage area and therefore bound more rhodoliths. Moreover, H. semitubulosa live almost completely buried and was usually binding rhodoliths of the beds surface and those about $5 \mathrm{~cm}$ below the surface of sediment. Other sponge species such as Dysidea cachui and

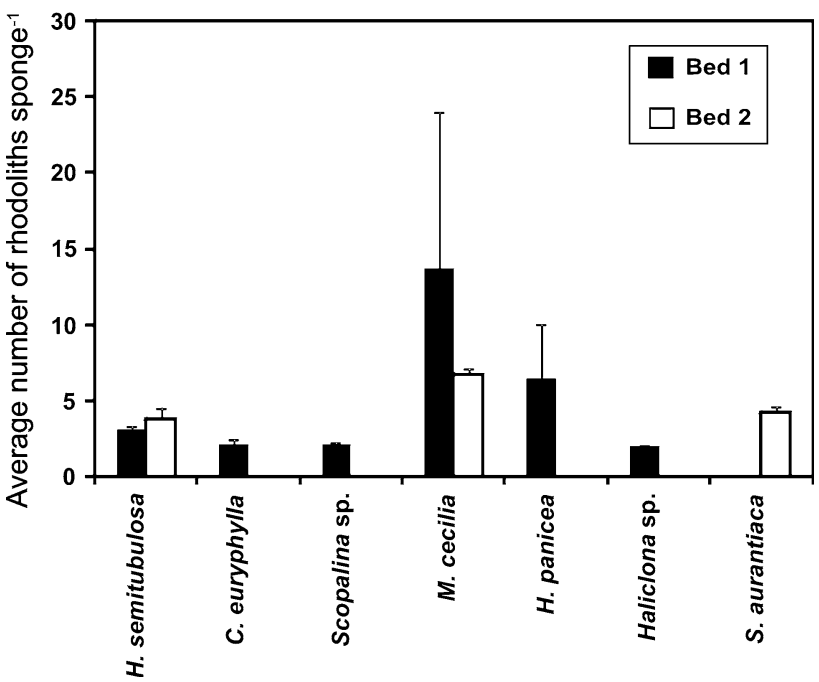

Fig. 4 Mean $( \pm$ SE) number of rhodoliths bind per sponge individual in two rhodolith beds of Bahia Magdalena

Mycale cf. magnirhapidifera usually attached and grew on a single rhodolith, which could also contribute to rhodolith stabilization by affecting their sphericity.

Brief description of the sponge-rhodolith interactions

Most of sponge species were of encrusting to massive growth form. They overgrew (partially or totally) and filled the space between the rhodolith branches (Fig. 2e, g, h) There was no apparent damage on the tissue of these algae as a result of this interaction. When sponges were detached from rhodoliths, a stronger pigmentation was observed on this area. Individuals of $H$. semitubulosa were often found almost totally covered by sediment, and only the growth 
projections and chimney-like siphons protruded from the sediment surface (Fig. 2c). This species developed a wide basal area and finger-like branches. H. semitubulosa and $M$. cecilia seem to be the main binding agents, as they were often found to glue together many rhodoliths.

Papillae of the boring species Cliona californiana and C. euryphylla were commonly observed protruding among rhodolith branches (Fig. 2g, h). In many cases, the rhodolith nuclei (gastropod or bivalve shells) was also infested by these species. Rhodoliths containing boring sponges were relatively more brittle than individuals without these sponges.

\section{Discussion}

The five rhodolith beds studied were dominated by L. margaritae, a common coralline alga in the region (Riosmena-Rodriguez et al. 1999), whose structural characteristics (average size, rhodolith density and branch density) were within the range of other previously recorded L. margaritae beds (Steller et al. 2003; Hinojosa-Arango and Riosmena-Rodríguez 2004). Likewise, the morphological characteristics of these seaweeds indicated that these populations were subject to high hydrodynamic conditions (tidal currents) (Steller et al. 2003). According to the previous studies, the spatial differences in size and branch density could be related to differences in the hydrodynamic conditions and to the intensity of light and its penetration into the water (Marrack 1999).

Our results revealed that areas adjacent to rhodolith beds almost always lacked sponges. These findings confirm the importance of these macroalgae as available hard substrate (Rocha et al. 2006) for associated sponges in estuarine environments, where sandy bottoms are predominant. It is important to mention that most of the sponge species found in this study have also been recorded in other environments of the Mexican Pacific such as rocky shores and associated with Sargassum beds (Carballo et al. 2008; Ávila et al. 2010). However, at Bahia Magdalena, these sponges were rarely observed in other hard substrates such as mangrove roots, rocky platforms or sandy flats. The low presence of sponges in these other substrates could be due to the large tidal range observed within this system (up to $2.3 \mathrm{~m}$ during spring tide) (Zaitsev et al. 2010). Only Mycale cf. parishi and Craniella sp. were occasionally found on soft bottoms, although their abundance was not quantified.

The species richness and abundance of associated sponges was positively related to rhodolith density, suggesting that the density of rhodoliths appears to be a good predictor of abundance and species richness of associated sponges. Similarly, Steller et al. (2003) documented that $L$. margaritae beds contribute significantly to the benthic biodiversity at Bahia Concepcion, within the Gulf of California, as richness and abundance of associated faunal species were significantly higher inside rhodolith beds than outside. Our results are in agreement with the suggestion that rhodoliths serve as substrate, refuge or recruitment areas to many organisms (e.g., Barbera et al. 2003; Peña and Bárbara 2007).

Along with substrate availability and complexity, differences in the physical environment (e.g., hydrodynamics and sedimentation rate) also play an important role in spatial variability in abundance and richness of sponges (Carballo et al. 2008). Although these environmental variables were not examined in this study, differences in sponge assemblages detected between sites could be partially related to different degrees of exposure within the bay.

Worldwide, there are a few studies documenting the sponge diversity on rhodolith beds. For example, in maerl beds from the Ria de Arousa (Galicia, Spain), a total of 39 sponge species were recorded (Solórzano et al. 1991). In deeper rhodolith beds from the western Mediterranean seamounts (up to $100 \mathrm{~m}$ depth), Aguilar et al. (2009) identified more than 30 species, and in Ningaloo Reef (Western Australia, between 18 and $102 \mathrm{~m}$ depth), Heyward et al. (2010) reported 155 sponge species associated with rhodolith beds. In this study, the total sponge richness was much lower (13 species); however, this is the first study documenting the diversity and abundance of sponges on rhodoliths beds in the Eastern Pacific. Both the density (max. 52 ind $\mathrm{m}^{-2}$ ) and richness (max. 6.1 species $\mathrm{m}^{-2}$ ) of sponges were comparable with those reported in rocky habitats (17.5 ind $\mathrm{m}^{-2}$ and 4.3 species $\mathrm{m}^{-2}$, Bell and Carballo 2008; Carballo et al. 2008) and Sargassum beds (23.9 ind $\mathrm{m}^{-2}$ and 4.8 species $\mathrm{m}^{-2}$, Ávila et al. 2010) of the region.

Although abundance and richness of sponges were not significantly related to size and branch density of rhodoliths, the highest values were found in bed 1. This site presents more closely branched rhodoliths and a higher percentage of spherical forms. Similar findings were documented in rhodolith beds from Maltese Islands (Mediterranean), where the high epifaunal species richness was related to closely branched rhodoliths (Sciberras et al. 2009).

According to the previous studies on these algae, high branch density and a predominance of spherical shapes are indicative of sites exposed to high water motion (Marrack 1999; Steller and Foster 1995). High water activity could also explain in part the relatively higher abundance of sponges, as these organisms require a constant renewal of large water volume to their filter-feeding activities. It is important to mention that bed 1 is positioned at the entrance of a relatively narrow channel closer to the mouth of the bay, which may improve the water flow and could 
make it different in sponge abundance and rhodolith shape compared to the other beds. In accordance with a previous study conducted in four of these beds, a non-metric multidimensional scaling (MDS) analysis using presence/ absence sponge species data revealed variability in the distribution of sponge assemblages among and within sites, which is likely the result of differences in environmental conditions (Ávila and Riosmena-Rodríguez 2011).

In this study, more than $50 \%$ of sponge species (with lateral growth) were found to bind rhodoliths $(3.7 \pm 0.2$ rhodoliths per sponge individual in average). This indicates that sponges could contribute to immobilization of these unstable biogenic substrata, just as they do in coral reefs and rocky habitats (see review in Bell 2008). In coral reefs, for example, sponges may increase the survival of live coral on Caribbean reefs by binding fragments together, which is expected to increase rates of carbonate accretion (Wulff and Buss 1979). The substrate stability may also enhance the chance of larval settlement of associated organisms (Rasser and Riegl 2002). In rocky habitats, it has been suggested that the stabilization of boulders by sponges and other organisms could potentially reduce disturbance levels (Bell and Barnes 2003). In the rhodolith beds of Bahia Magdalena, sponges could minimize the effects of hydrodynamic conditions, such as tidal currents and storm disturbances, although it is not known to what degree this occurs or its actual effect.

The immobilization of rhodoliths by epibionts could also have potential negative effects. The lower portions of the seaweeds that are in contact with the sediment may be affected, as this area can become anoxic. Our observations of rhodoliths from the Magdalena region point to a distinctive growth pattern for long-term stabilized rhodoliths. They tend to develop thalli with a mushroom-like shape where the sand covered section is dead and the exposed part is still alive. On the other hand, it has also been demonstrated that rhodoliths can survive without movement as they can translocate metabolites to lower surfaces of the thalli or have some heterotrophic utilization of a dissolved energy source, allowing them to grow spherically (Littler et al. 1991). Also, Scoffin et al. (1985) reported that spherical rhodoliths can continue to live under sandy substrata because water flushing through the sand and gravel may move sediment grains. Moreover, some stabilization experiments have resulted in the softening of rhodoliths and breakage of thalli after 6 months of permanent stabilization as a result of overgrowth by tube building amphipod species (Hinojosa-Arango personal comments).

In summary, the results of the present study indicated that shallow-water L. margaritae beds constitute an important solid substrate for sponge assemblages in soft bottoms from Bahia Magdalena, since sponges were largely confined to these biogenic substrates as occur in other macroalgal habitats (Ávila et al. 2010). The significant positive relationships between sponge density and rhodolith density and between sponge species richness and rhodolith density support this fact. Moreover, many of the sponge species recorded here were identified as binding agents of rhodoliths, suggesting an important role in rhodolith stabilization by minimizing effects of hydrodynamic conditions. Further studies are needed for a better understanding of the dynamics of these sponge-rhodolith interactions and their role in estuarine ecosystems.

Acknowledgments We would like to thank López-Vivas JM, Sánchez-Rodríguez A and López-Calderón J for their help during field sampling and The School for Field Studies, México, for usage of SCUBA equipment and facilities. We thank Romero A, Inzunza F and Romero $\mathrm{C}$ for their help carrying out field work. E. Ávila also thanks CONACYT for the financial support (Postdoctoral Grant) and R. Riosmena-Rodríguez thanks the CONACYT-SEMARNAT fund for financial support of this study.

\section{References}

Aguilar R, Pastor X, Torriente A, García S (2009) Deep-sea coralligenous beds observed with ROV on four seamounts in the western Mediterranean. Primer simposio Mediterráneo sobre coralígeno y otras bio-concreciones calcáreas, Madrid Spain. http://www.oceana.org/index.php?id=2845\&L=2. Accessed 17 Jan 2012

Ávila E, Riosmena-Rodríguez R (2011) A preliminary evaluation of shallow-water rhodolith beds of Bahia Magdalena, Mexico. Braz J Oceanogr 59:365-375

Ávila E, Blancas-Gallangos NI, Riosmena-Rodríguez R, Paul-Chávez L (2010) Sponges associated with Sargassum spp. (Phaeophyceae: fucales) from the South-Western Gulf of California. J Mar Biol Assoc U.K. 90:193-202

Bahia RG, Abrantes DP, Brasileiro PS, Pereira-Filho GH, AmadoFilho GM (2010) Rhodolith bed structure along a depth gradient on the northern coast of bahia state. Braz J oceanogr 58:323-337

Barbera C, Bordehore C, Borg JA, Glémarec M, Grall J, Hall-Spencer JM, De la Huz CH, Lanfranco E, Lastra M, Moore PG, Mora J, Pita ME, Ramos-Esplá AA, Rizzo M, Sánchez-Mata A, Seva A, Schembri PJ, Valle C (2003) Conservation and management of northeast Atlantic and Mediterranean maërl beds. Aquat Conserv Mar Freshw Ecosyst 13:65-76

Bell JJ (2008) The functional roles of marine sponges. Estuar Coast Shelf Sci 79:341-353

Bell JJ, Barnes DKA (2003) Effect of disturbance on assemblages: an example using Porifera. Biol Bull 205:144-159

Bell JJ, Carballo JL (2008) Patterns of sponge biodiversity and abundance across different biogeographic regions. Mar Biol 155:563-570

Bosence DWJ, Pedley HM (1982) Sedimentology and palaeoecology of a Miocene coralline algal biostrome from the Maltese Islands. Palaeogeogr Palaeoclimatol Palaeoecol 38:9-43

Calcinai B, Cerrano C, Totti C, Romagnoli T, Bavestrello G (2006) Symbiosis of Mycale (Mycale) vansoesti sp. nov. (Porifera, Demospongiae) with a coralline alga from North Sulawesi (Indonesia). Invertebr Biol 125:195-204

Carballo JL, Ávila E, Enríquez S, Camacho L (2006) Phenotypic plasticity in a mutualistic association between the sponge Haliclona caerulea and the calcareous macroalga Jania 
adherens induced by transplanting experiments. I: morphological responses of the sponge. Mar Biol 148:467-478

Carballo JL, Vega C, Cruz-Barraza JA, Yáñez B, Nava H, Ávila E, Wilson M (2008) Short and long-term patterns of sponge diversity on rocky tropical coast: evidence of large structuring factors. Mar Ecol Evol Persp 29:216-236

Davy SK, Trautman DA, Borowitzka MA, Hinde R (2002) Ammonium excretion and its ecological importance in a spongerhodophyte symbiosis. J Exp Biol 205:3505-3511

Enríquez S, Ávila E, Carballo JL (2009) Phenotypic plasticity induced in transplant experiments in a mutualistic association between the red alga Jania adhaerens (Rhodophyta, Corallinales) and the sponge Haliclona caerulea (Porifera: haplosclerida): morphological responses of the alga. J Phycol 45:81-90

Foster MS (2001) Rhodoliths: between rocks and soft places. J Phycol 37:659-667

Foster MS, Riosmena-Rodríguez R, Steller DL, Woelkerling WJ (1997) Living rhodolith beds in the Gulf of California and their implications for paleoenvironmental interpretation. Geol Soc Am 318:127-139

Graham DJ, Midgley NG (2000) Graphical representation of particle shape using triangular diagrams: an excel spreadsheet method. Earth Surf Proc Land 25:1473-1477

Grant AJ, Hinde RT (1999) Evidence of transfer of photosynthate from a red algal macrophyte to its symbiotic sponge. Mem Queens Mus 44:204

Harvey AS, Bird FL (2008) Community structure of a rhodolith bed from cold-temperate waters (southern Australia). Aust J Bot $56: 437-450$

Heyward A, Fromont J, Schönberg CHL, Colquhoun J, Radford B, Gomez O (2010) The sponge gardens of Ningaloo Reef, western Australia. Open Mar Biol J 4:3-11

Hinojosa-Arango G, Riosmena-Rodríguez R (2004) The influence of rhodolith species and growth-form on cryptofaunal assemblages of rhodolith beds in the central-west Gulf of California, Mexico. PSZN Mar Ecol 54:234-244

Lankford RR (1977) Coastal lagoons of Mexico: Their origin and classification. In: Wiley M (ed) Estuarine Processes. Academic, New York, pp 182-215

Leal RN, Bassi D, Posenato R, Amado-Filho GM (2012) Tomographic analysis for bioerosion signatures in shallow-water rhodoliths from the Abrolhos Bank, Brazil. J Coast Res 28: 306-309

Littler MM, Littler DS, Hanisak MD (1991) Deepwater rhodolith, productivity, and growth history at sites of formation and subsequent degradation. J Exp Mar Biol Ecol 150:163-182

Lluch-Belda D, Hernández-Rivas M, Saldierna-Martínez R, GuerreroCaballero R (2000) Variabilidad de la temperatura superficial del mar en Bahía Magdalena, B.C.S. Oceánides 15:11-23

Marrack EC (1999) The relationship between water motion and living rhodolith beds in the southwestern Gulf of California, Mexico. Palaios 14:159-171

Obeso-Nieblas M, Gavino-Rodríguez JH, Jiménez-Illescas AR (1999) Modelación de la marea en el sistema lagunar Bahía MagdalenaAlmejas, B.C.S. México Oceánides 14:79-88

Peña V, Bárbara I (2007) Maërl community in the northwestern Iberian Peninsula: a review of floristic studies and long-term changes. Aquat Conserv Mar Freshw Ecosyst 17:1-28

Rasser MW, Riegl B (2002) Holocene coral reef rubble and its binding agents. Coral Reefs 21:57-72
Riosmena-Rodriguez R, Woelkerling WJ, Foster MS (1999) Taxonomic reassessment of rhodolith-forming species of Lithophyllum (Corallinales, Rhodophyta) in the Gulf of California, Mexico. Phycologia 38:401-417

Rocha RM, Metri R, Muro JY (2006) Spatial distribution and abundance of ascidians in a bank of coralline algae at Porto Norte, Arvoredo Island, Santa Catarina. J Coast Res Spec Issue 39:1676-1679

Rützler K (1990) Associations between Caribbean sponges and photosynthetic organisms. In: Rützler K (ed) New perspectives in sponge biology. Smithsonian Institution Press, Washington DC, pp 455-466

Schweers T, Wolff M, Koch V, Sinsel-Duarte F (2006) Population dynamics of Megapitaria squalida (Bivalvia: veneridae) at Magdalena Bay, Baja California Sur, México. Rev Biol Trop 54:1003-1017

Sciberras M, Rizzo M, Mifsud JR, Camilleri K, Borg JA, Lanfranco E, Schembri PJ (2009) Habitat structure and biological characteristics of a maerl bed off the northeastern coast of the Maltese Islands (central Mediterranean). Mar Biodiv 39:251-264

Scoffin TP, Hendry MD (1984) Shallow-watersclerosponges on Jamaican reefs and a criterion for recognition of hurricane deposits. Nature 307:728-729

Scoffin TP, Stoddart DR, Tudhope AW, Woodroffe C (1985) Rhodoliths and coralliths of Muri Lagoon, Rarotonga, Cook Islands. Coral Reefs 4:71-80

Sokal RR, Rohlf JH (1995) Biometry: the principles and practice of statistics in biological research. Freeman, New York

Solórzano M, Cristobo F, Urgorri V (1991) Introducción al poblamiento de poríferos de la biocenosis de maerl en la Ría de Arousa (Galicia, España). Bol R Soc Esp Hist Nat 87:175-185

Steller DL, Foster MS (1995) Environmental factors influencing distribution and morphology of rhodoliths in Bahia Concepcion, B.C.S. Mexico J Exp Mar Biol Ecol 194:201-212

Steller DL, Riosmena-Rodríguez R, Foster MS, Roberts CA (2003) Rhodolith bed diversity in the Gulf of California: the importance of rhodolith structure and consequences of disturbance. Aquat Conserv Mar Freshw Ecosyst 13:5-20

Trautman DA, Hinde R, Borowitzka MA (2000) Population dynamics of an association between a coral reef sponge and a red macroalga. J Exp Mar Biol Ecol 244:87-105

Vacelet J (1981) Algal-sponge symbioses in the coral reef of New Caledonia: a morphological study. Proc 4th Int Coral Reef Symp. Manila 2:713-719

Wulff JL (1984) Sponge-mediated coral reef growth and rejuvenation. Coral Reefs 3:157-163

Wulff JL (1997) Causes and consequences of differences in sponges diversity and abundance between the Caribbean and eastern Pacific at Panama. Proc 8th Int Coral Reef Symp, Panama, pp 1377-382

Wulff JL (2006) Ecological interactions of marine sponges. Can J Zool 84:146-166

Wulff JL, Buss LW (1979) Do sponges help hold coral reefs together? Nature 281:474-475

Zaitsev O, Sánchez-Montante O, Saldivar-Reyes M (2010) Seasonal variations of the thermohaline structure in the MagdalenaAlmejas Bay lagoon system and adjacent sea. Cienc Mar $36: 413-432$ 